\title{
Penerapan E-Reporting sebagai Upaya Peningkatan Akuntabilitas dan Transparansi Pengelolaan Dana Masjid Baiturahman Semarang
}

\author{
Edy Suprianto*1, Dedi Rusdi²
}

\author{
1,2Jurusan Akuntansi, Universitas Islam Sultan Agung, Indonesia \\ *e-mail: edysuprianto@unissula.ac.id ${ }^{1}{ }_{\text {dedirusdi@unissula.ac.id }}^{2}$
}

\begin{abstract}
Abstrak
Tujuan dari pengabdian ini adalah memberikan kontribusi pada masyarakat khususnya bagi Masjid Baiturahman dalam menyusun laporan keuangan. Hal ini perlu dilakukan untuk dapat menyelesaikan permasalahan keuangan yang dihadapi yaitu kesulitan penyusunan laporan keuangan yang sesuai dengan standar akuntansi. Tuntutan akuntabilitas dan transparansi laporan keuangan menjadi alasan mengapa Masjid Baiturahman yang terletak di tengah kota Semarang ini harus Menyusun laporan keuangan. Pengabdian dilakukan secara bertahap, pertama dilakukan penyuluhan sistem akuntansi yang baik kepada pengurus masjid dan Yayasan, kedua dilakukan FGD untuk dapat mendesain laporan keuangan berbasis web sesuai dengan standar akuntnsi yang berlaku. Setelah dilakukan pelatihan dan FGD tim pengabdian telah mampu mendesainkan sistem akuntansi berbasis web atau disebut E-Reporting Masjid. Diharapkan pengabdian ini dapat memberikan manfaat bagi pengurus masjid Baiturahman di Kota semarang untuk dapat meningkatkan transparansi dan akuntabilitas laporan keuangan masjid.
\end{abstract}

Kata kunci: Akuntabilitas, Laporan Keuangan Masjid, Transparansi

\begin{abstract}
The purpose of this service is to contribute to the community, especially for the Baiturahman Mosque in preparing financial reports. This needs to be done to be able to solve the financial problems faced, namely the difficulty of preparing financial statements in accordance with accounting standards. The service is carried out in stages, firstly, counseling on a good accounting sistem to mosque administrators and foundations, secondly FGDs are conducted to be able to design web-based financial reports in accordance with applicable accounting standards. After training and FGD the service team has been able to design a web-based accounting sistem or called Mosque E-Reporting. It is hoped that this service can provide benefits for the Baiturahman mosque management in Semarang City to be able to increase the transparency and accountability of mosque financial reports access article under the.
\end{abstract}

Keywords: Accountability, Mosque Financial Report, Transparency

\section{PENDAHULUAN}

Selama ini pola pertanggungjawaban masjid-masjid yang ada di kota semarang dilakukan setiap seminggu sekali pada saat ibadah sholat jum'at. Laporan ini berbentuk informasi kas minggu yang berisi jumlah penerimaan dan penggunaan kas masjid selama 1 minggu. Hasil survey yang kami lakukan menunjukan pengelola masjid tidak mampu membuat laporan keuangan misalnya Neraca, laporan aktivitas dan lain-lain. Hal ini sama dengan di beberapa masjid di tempat lain (Susilawati et al., 2020).

Jika melihat beberapa penelitian dan pengabdian masyarakat yang dilakukan sebelumnya seperti Suratman et al. (2019) melaporkan bahwa beberapa masjid masih belum mampu Menyusun laporan keuangan seperti Laporan Posisi Keuangan, Laporan Aktivitas, Laporan Arus Kas, dan laporan Perubahan Ekuitas. Nariasih et al. (2017) juga melaporkan bahwa laporan keuangan yang telah disusun oleh masjid XYZ selama ini masih belum sesuai dengan PSAK Nomor 45 dan atau PSAK Nomor 109. Fauzi \& Setyaningsih (2020) menyatakan bahwa pengelola masjid masih belum menerapkan PSAK 45 dalam penyusunan laporan keuangannya.

Masjid Baiturahman yang terletak di tengah kota Semarang, tepatnya di simpanglima Semarang. Sebenarnya potensi penerimaan dari masjid ini cukup besar, namun pelaporan yang kurang terinci dan akuntable dapat menyebabkan laporan keuangan masjid kepada umat 
cenderung masih sederhana. Masjid tidak mampu menunjukan secara langsung berapa aset yang dimiliki, Termasuk juga bagaimana kinerja takmir masjid selama ini. Apakah sudah sesuai dengan harapan masyarakat atau belum. Perlu ada sistem pelaporan yang transparan dan akuntabel untuk dapat mengatasi masalah ini.

Pencatatan sistem pembukuan dan keuangan masjid Baiturahman yang masih sederhana, cenderung menimbulkan pertanyaan di masyarakat. Hal ini juga akan dapat menimbulkan masalah-masalah lain yang di kemudian hari akan timbul, misalnya kesalahan pencatatan, tidak dicatat, tidak disetor hingga penggelapan. Masyarakat selama ini merasa bahwa dirasa masih kurang efektif dalam meningkatkan kualitas laporan keuangan masjid. Mereka menyadari bahwa penting baginya untuk melaporkan kondisi riil masjid baik dana yang diperoleh dari sumber publik, dan dari pemerintah. Masjid ini juga menghadapi masalah yang sama yaitu belum mampu mempertanggungjawabkan laporan keuangan secara transparansi dan akuntable. Mereka belum dapat membuat laporan keuangan secara baik dan benar. Selama ini mereka telah berusaha untuk mempertanggungjawabkan dana bantuan dalam bentuk laporan penggunaan dana beserta buktinya. Namun, minimnya sumber daya manusia di bidang akuntansi, dirasa perlu untuk melakukan pendampingan secara khusus kepada seluruh pengurus masjid tersebut.

Berdasarkan latar belakang di atas maka penting sekali bagi kami untuk membantu memecahkan masalah untuk memberikan suatu pelatihan yang lebih mendalam tentang proses akuntansi dan mendesainkan laporan keuangan berbasis web sesuai dengan standar akuntansi. Diharapkan mereka akan dapat menyusun laporan keuangan secara baik, transparan dan akuntabel. Target pengabdian ini adalah untuk dapat memberikan pengalaman dan praktik langsung tentang bagaimana cara penyusunan laporan keuangan bagi semua pengurus masjid di kota semarang. Diharapkan pengabdian ini dapat memberikan manfaat bagi seluruh pengurus masjid di Kota semarang untuk dapat meningkatkan transparansi dan akuntabilitas laporan keuangan masjid. Luaran dalam pengabdian masyarakat ini adalah teknologi berupa laporan keuangan masjid yang berbasis web. Penggunakan teknologi informasi dapat meningkatkan kualitas informasi suatu institusi. Teknologi sangat berperan dalam meningkatkan kualitas laporan keuangan.

\section{METODE}

Mitra dalam pengabdian ini adalah pengurus masjid Baiturahman Semarang yang terletak di jalan simpang lima semarang yang berjumlah 2 orang. Termasuk juga pengurus yayasan sebanyak 1 orang yang ikut andil dalam pengambilan keputusan. Ada dua tahap yang akan dilakukan untuk meningkatkan kualitas laporan keuangan masjid, yaitu sebagai berikut:

\subsection{Tahap Pertama: Sosialisasi Sistem akuntansi Keuangan}

Langkah pertama yaitu dengan melakukan pendekatan secara pragmatis mengenai pentingnya suatu sistem organisasi yang profesional dan tata buku yang akuntabel dan transparan. Hal ini dapat dilakukan suatu bimbingan atau penyuluhan dengan pendekatan secara personal dengan para pengurus masjid.

\subsection{Tahap Kedua: FGD dengan Pengurus Masjid}

Langkah kedua berdiskusi secara langsung dengan pengurus Masjid Baiturahman tentang kemungkinan laporan keuangan masjid dapat disusun sesuai dengan standar akuntansi dan berbasis web.

Berikut ini adalah daftar hadir pengabdian pada masjid baiturahman semarang: 


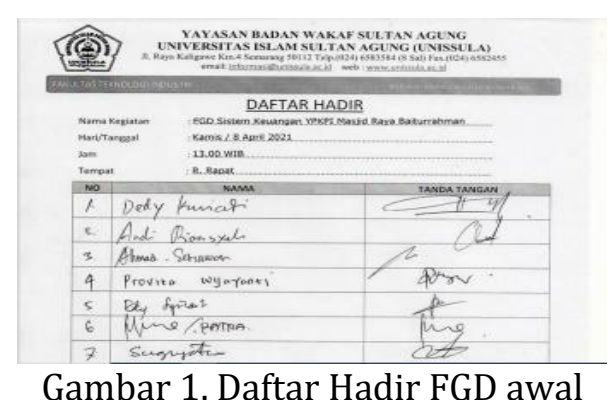

Gambar 1. Daftar Hadir FGD awal

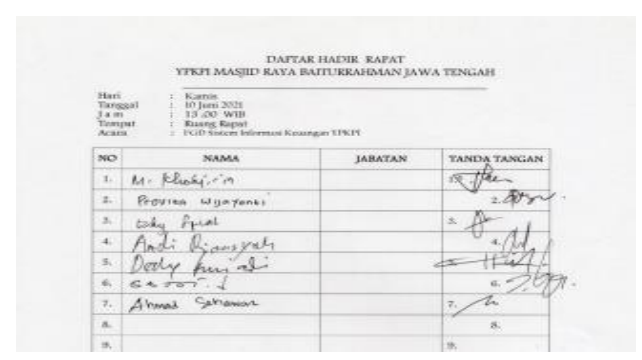

Gambar 2. Daftar Hadir FGD Kedua

\section{HASIL DAN PEMBAHASAN}

Pada pengabdian kali ini kami awali dengan pemaparan tentang sistem akuntansi keuangan secara umum. Kegiatan ini kami lakukan pada hari kamis tanggal 8 April 2021 bertempat di Ruang pertemuan Masjid Baiturahman Simpang lima Semarang. Kegiatan ini dihadiri oleh semua pengurus yayasan dan masjid Baiturahman. Berikut ini adalah foto proses pemaparan sistem akuntansi dihadapan pengurus yayasan dan masjid Baiturahman Simpang lima Semarang.

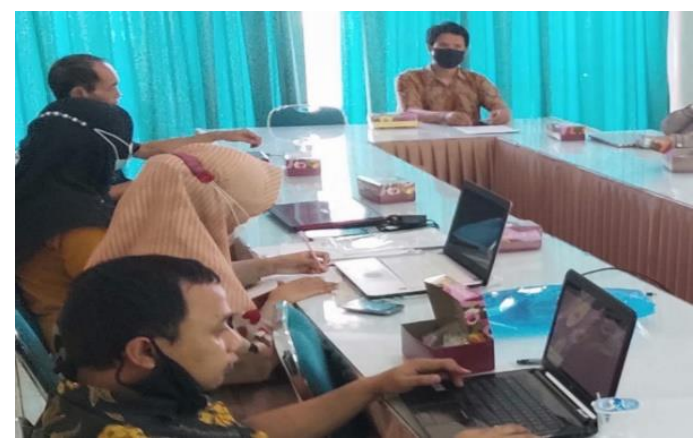

Gambar 3. pemaparan sistem akuntansi dihadapan pengurus yayasan dan masjid Baiturahman Simpang lima Semarang

Dengan melakukan pendekatan secara pragmatis mengenai pentingnya suatu sistem organisasi yang profesional dan tata buku yang akuntabel dan transparan. Hal ini dibutuhkan karena kondisi saat ini memang masjid Baiturahman belum memiliki laporan keuangan yang sesuai dengan standar akuntansi. Mereka masih menggunakan pembukuan yang sederhana. Hal ini sama seperti di masjid lainya seperti Syafitri \& Ulandari (2019) menyebutkan bahwa laporan keuangan Masjid Agung Nurul Huda belum sesuai dengan PSAK No. 45 karena masih menggunakan format sederhana berbentuk laporan pertanggunngjawaban keuangan yang disusun oleh pengurus terdahulu.

Pelatihan ini sebagai awal proses pengabdian kami dengan tujuan untuk memberikan pemahaman yang memadai tentang pentingnya laporan keuangan dan bagaimana proses penyusunan laporan keuangan. Hal ini sesuai dengan Nurillah et al. (2020) yang menyatakan bahwa kompetensi sumber daya manusia akan dapat bermanfaat dalam meningkatkan kualitas informasi laporan keuangan. 
Langkah selanjutnya tim pengabdian akan melakukan FGD dengan Pengurus Masjid. Langkah kedua berdiskusi secara langsung dengan pengurus Masjid Baiturahman tentang kemungkinan laporan keuangan masjid dapat disusun sesuai dengan standar akuntansi dan berbasis web. Kegiatan ini kami lakukan mulai dari bulan Mei 2021 hingga bulan Agustus 2021 ini. Berdasarkan hasil FGD kami mencoba mendesainkan laporan keuangan berbasis web dengan Kerjasama dengan Dosen Teknik Industri Unissula. Berikut ini adalah draft hasil pengembangan laporan keuangan yang berbasis web. Program ini masih draft akan kami kembangkan kembali sehingga menjadi final untuk dapat dimanfaatkan oleh semua masjid di jawa tengah. Berikut foto FGD tim pengabdian dengan Yayasan dan pengurus masjid Baiturahman.

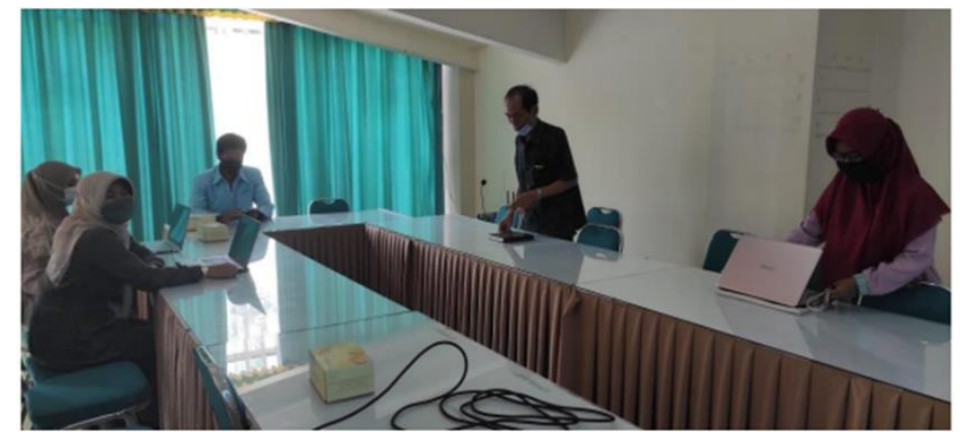

Gambar 4. FGD Tim Pengabdian dengan Pengurus Yayasan dan Masjid Baiturahman

Proses desain sistem laporna keuangan masjid berbasis web ini mengacu pada pengembangan yang dilakukan oleh Bulaeng dkk. (2019). Mereka mengembangkan sistem informasi keuangan Masjid Babul Muttaqien Parang Tambung dengan menggunakan model pengembangan prototyping. Sistem pengembangan dengan menggunakan bahasa pemrograman PHP dan pengelolaan database menggunakan MySQL. Hasil pengembangan menghasilkan sistem informasi keuangan Masjid Babul Muttaqien yang dikelola secara online yang digunakan dalam pengelolaan keuangan meliputi pemasukan, pengelolaan kas dan pengeluaran kas.

Proses pengembangan sistem akuntansi di masjid baiturahman ini didesain lebih terintegrasi antara Yayasan dan masjid Baiturahman dengan mendasarkan pada standar akuntansi yang berlaku. Basis pencatatan dengan menggunakan basis akuntansi akrual. User disediakan menu untuk melakukan proses pencatatan akuntansi melalui jurnal umum. Kemudian sistem akan melakukan nposting jurnal secara otomatis hingga menjadi laporan keuangan secara handal. Pengurus masjid dan Yayasan diberikan kemudahan dalam proses pembacaan dan analisis laporan keuangan sehingga bermanfaat dalam pengambilan keputusan. Dengan adanya sistem laporan keuangan baru ini saat ini mempermudah pengurus Masjid Baiturahman menjadi mudah menyusun laporan keuangan secara tepat waktu dan lebih cepat dibandingkan dengan sebelumnya.

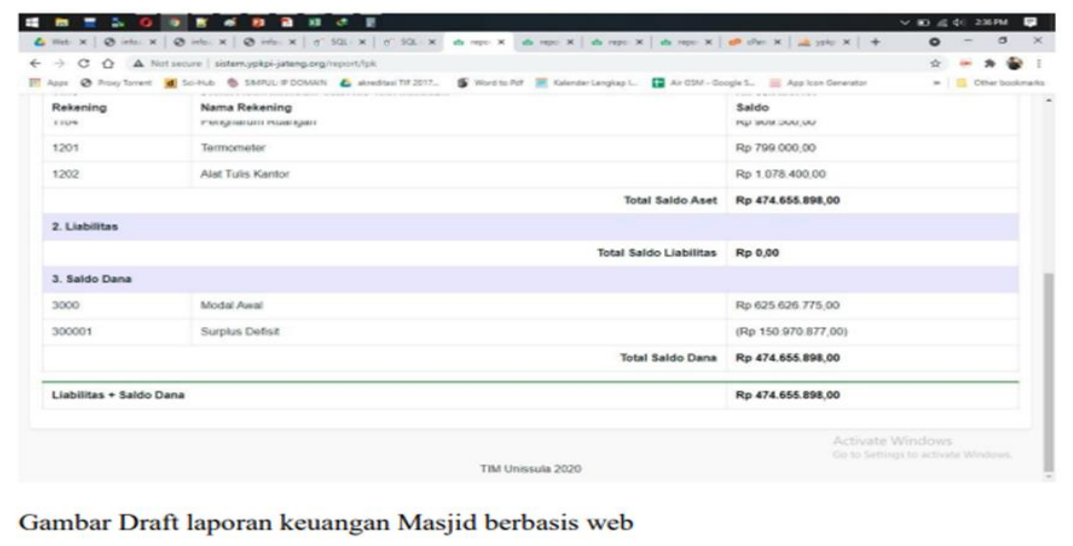

Gambar 5. Model Laporan Keuangan Masjid berbasis Web 


\section{KESIMPULAN}

Masjid Baiturahman yang terletak di jalan simpang lima tengah kota Semarang ini memiliki potensi penerimaan dari masjid ini cukup besar, namun pelaporan yang kurang terinci dan akuntable dapat menyebabkan tuntutan masyarakat sangat tinggi terhadap laporan keuangan masjid. Perlu ada sistem pelaporan yang transparan dan akuntabel untuk dapat mengatasi masalah ini. Solusi yang kami tawarkan yaitu memberikan pelatihan tentang sistem akuntansi dan mendesainkan sistem akuntansi yang cocok dengan kondisi di masjid Baiturahman. Tim pengabdian juga telah mendesainkan sistem laporan keuangan berbasis web yang memudahkan pengurus masjid dapat mengakses dimanapun juga. Diharapkan pengabdian ini dapat memberikan manfaat bagi pengurus masjid Baiturahman di Kota semarang untuk dapat meningkatkan transparansi dan akuntabilitas laporan keuangan masjid.

\section{UCAPAN TERIMA KASIH}

Tim penulis mengucapkan terima kasih kepada Lembaga Penelitian dan Pengabdian Masyarakat (LPPM) Universitas Islam Sultan Agung yang telah mendanai kegiatan pengabdian ini sehingga terlaksana dengan baik.

\section{DAFTAR PUSTAKA}

Bulaeng, A. M., Bakri, H., \& Sidin, U. S. (2019). Pengembangan Sistem Informasi Keuangan Masjid Babul Muttaqien Parang Tambung Kota Makassar. Jurnal MediaTIK, 1(1), 54-61.

Fauzi, M. R. C., \& Setyaningsih, N. D. (2020). Penyusunan Laporan Keuangan Masjid Berdasarkan Psak 45. EL Muhasaba Jurnal Akuntansi, 11(2), 114-122. https://doi.org/10.18860/em.v11i2.7645

Nariasih, D. Y., Kurrohman, T., \& Andriana. (2017). Laporan Keuangan Masjid Berdasarkan Kombinasi PSAK Nomor 45 dan PSAK Nomor 109 (Studi Kasus Pada Masjid XYZ). E-Journal Ekonomi Bisnis Dan Akuntansi, 4(1), 6. https://doi.org/10.19184/ejeba.v4i1.4553

Nurillah, N. M., Cahyaningsih, \& Zultilisna, D. (2020). Analisis Faktor-Faktor yang Memengaruhi Kualitas Informasi Laporan Keuangan pada Masjid. Studi Akuntansi Dan Keuangan Indonesia, 3(2), 184-212. https://doi.org/10.21632/saki.3.2.184-212

Suratman, Yulianti, \& Wahdi, N. (2019). Pendampingan Penyusunan Aplikasi Laporan Keuangan. Jurnal Masyarakat Mandiri (JMM), 3(2), 139-147.

Susilawati, L., Sriwardany, \& Nasution, A. A. (2020). Penyusunan Laporan Keuangan Masjiddan Potensi Dana Masjid (Studi Kasus Di Masjid Medan Selatan Kecamatan Medan Maimun). Prosiding Seminar Seminar Hasil Penelitian 2019, 392-398. https://eprosiding.umnaw.ac.id/index.php/penelitian/article/view/567

Syafitri, D. I., \& Ulandari, V. (2019). Analisis Laporan Keuangan Masjid Berdasarkan PSAK No. 45 Tentang Pelaporan Keuangan Organisasi Nirlaba (Studi Kasus di Masjid Agung Nurul Huda Sumbawa Besar). Jurnal Ekonomi Dan Bisnis Indonesia, 4(1), 45-50. https://doi.org/10.37673/jebi.v4i1.276 


\section{Halaman Ini Dikosongkan}

